\title{
Tapped lakes as sediment traps in an Arctic delta
}

\author{
JESSE WALKER ${ }^{1} \&$ MOLLY MCGRAW ${ }^{2}$ \\ 1 Department of Geography, Louisiana State University, Baton Rouge, Louisiana 70803, USA \\ hwalker@1su.edu \\ 2 Department of Sociology, Southeastern Louisiana University, Hammond, Louisiana 70402, USA
}

\begin{abstract}
Lakes within the Colville River delta in northern Alaska, USA, vary in size from small ponds created by ice-wedge growth to thaw lakes that are as much as three kilometres long and ten metres deep. As the river migrates, lake edges are breached and the lakes are drained. Such lake tapping is aided by permafrost thaw and ice wedge melt and, in the case of the larger lakes, by wave action within them. Once a lake is tapped, it drains rapidly creating a deep scour hole at its entrance and from then on it is subject to the varying stages and discharge of the river. During flooding, when the river is transporting its largest amount of sediment, the tapped lakes become settling basins and rapidly fill. The Colville River delta has lakes in all stages from freshly breached to those that are now being destroyed by channel migration.
\end{abstract}

Key words delta; lake; flooding; erosion; deposition; Colville, Alaska; Arctic

\section{INTRODUCTION}

The North American Arctic Coastal Plain extends from the Chukchi Sea eastward across northern Alaska and Canada's Yukon Territory, and then northeast to Meighen Island. It ranges in width from 15 to $150 \mathrm{~km}$ with the largest extent being in northern Alaska. Among its most distinctive features are the oriented lakes that are especially numerous in northern Alaska and on the Tuktotyaktuk Peninsula in Canada. Because of their distinctive characteristics they have received the bulk of the research devoted to lakes in the area (Carter et al. 1987, Jorgenson \& Shur 2007). In contrast are those lakes that are present in the two major deltas that lie in the Coastal Plain: the Mackenzie (Canada) and the Colville (USA). Although the Colville River delta (Fig. 1(a)) is small $\left(\sim 600 \mathrm{~km}^{2}\right)$ in comparison with other arctic deltas, it contains all of the forms and exhibits all of the processes that prevail in the region. It is used here to illustrate how the combination of forms and processes result in the conversion of lakes through tapping into sediment traps or small depo-centers.

\section{THE COLVILLE DELTA: ITS LAKES AND PONDS}

The Colville River delta is a maze of lakes and ponds (Fig. 1(b)). They range in length from a few metres to more than $3 \mathrm{~km}$; in area from a few $\mathrm{m}^{2}$ to more than $2.5 \mathrm{~km}^{2}$; in depth from a few $\mathrm{cm}$ to $\sim 10 \mathrm{~m}$; and in shape from nearly circular to very elongated. Although the number of large lakes in the delta was calculated in the $1960 \mathrm{~s}$, it was not until the development of modern-day computers, satellite imagery and sophisticated programs that the smaller water bodies could be included in the tabulation. In 2011, seven lakes had areas of more than $2 \mathrm{~km}^{2}$ whereas more than 235000 had areas of less than $0.0125 \mathrm{~km}^{2}$ (McGraw \& Walker 2013).

The types of lakes and ponds in the delta include: 1. low-centred ice-wedge polygons and the troughs between polygons, 2. perched ponds within and between sand dunes, 3. terrace flank depressions, 4. abandoned river channels (oxbow lakes), 5. swales within ridge and swale deposits, 6. ice-scour holes, 7. thaw lakes, and 8. possibly the remnants of oriented lakes (Dawson 1975). All of them are subject to extreme climatic conditions and are covered with ice and snow for as much as eight months of the year. In addition, all of the delta's water bodies are surrounded by, and most of them are underlain by, permafrost. Exceptions are those lakes and distributary channels that are deeper than $\sim 2 \mathrm{~m}$, i.e. those that do not freeze to the bottom during winter. They are underlain by un-frozen zones known as taliks.

\section{LAKE MODIFICATION AND TAPPING}

Arctic deltas, like those in other climatic regions, are dynamic. In arctic deltas, flooding and riverice breakup are seasonal and the erosion and deposition that accompany them regularly cause 

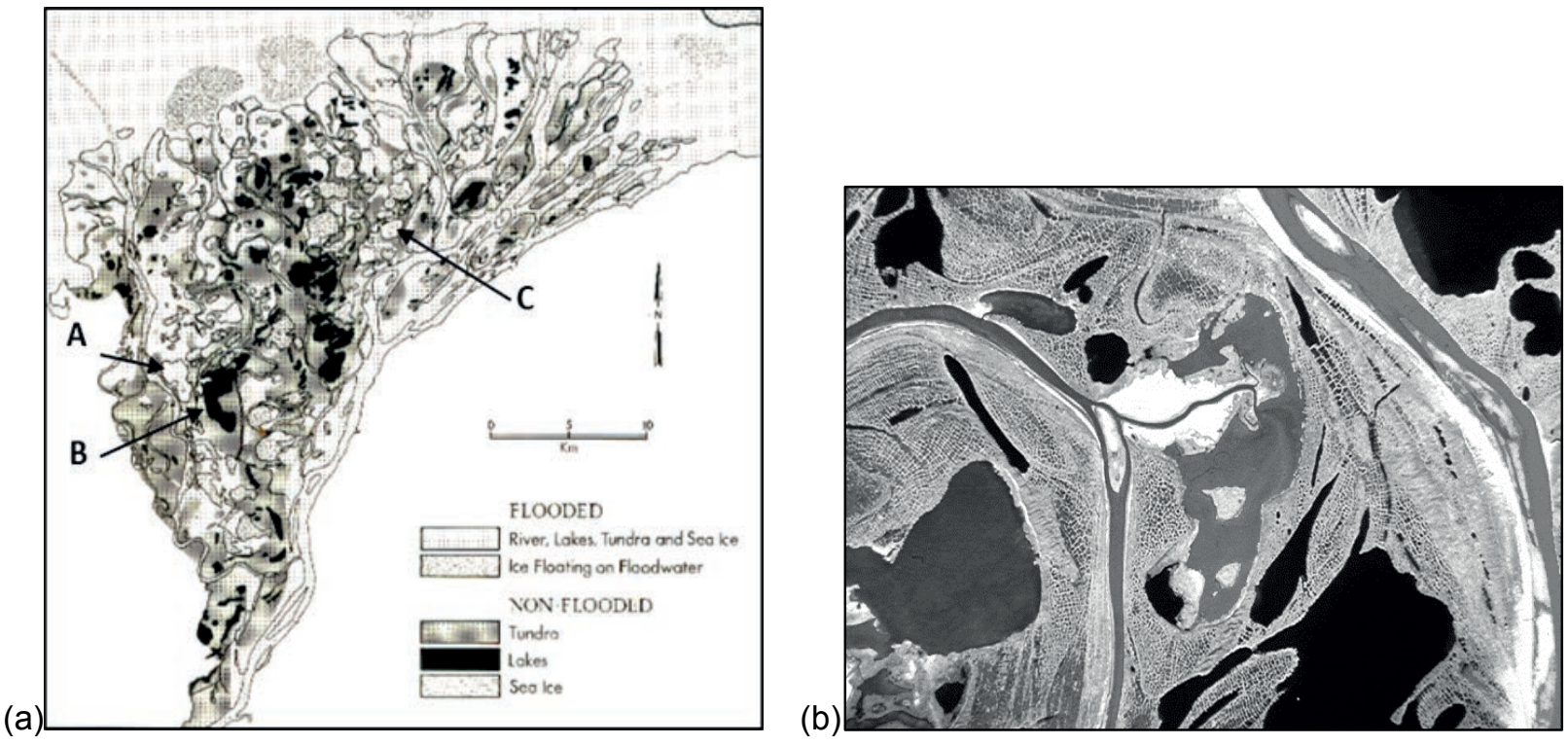

Fig. 1 (a) The Colville River delta during flood. (b) Detail of the Colville River delta lakes.

major morphological changes. During extreme events, flooding impacts as much as two-thirds of the delta's surface and therefore a majority of its lakes and ponds (Walker 1973).

\section{Ice-wedge melt and permafrost thaw as lake modifiers}

Most large lakes and many sections of the distributaries, especially those composed of peat, have banks that are bordered by ice-wedge polygons (Ritchie \& Walker 1974). Ice wedges vary in width up to more than $2 \mathrm{~m}$ and in depth to more than $5 \mathrm{~m}$. When exposed the ice is subject to melting and the frozen surrounding materials to thawing. Because the melt rate of ice wedges, especially those within banks of peat, is faster than permafrost's thaw rate, the bank line becomes serrated. Within the lake itself such retreat often results in an inversion of relief (Fig. 2).

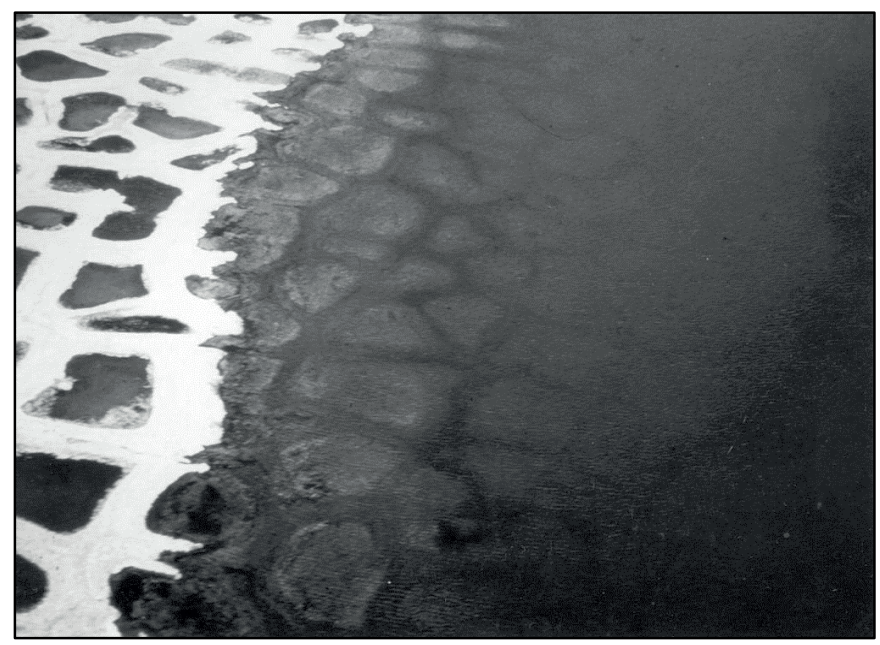

Fig. 2 Relief inversion due to ice wedge melt.

\section{Lake ice, wind and waves}

Before the melt season begins, lake ice on the deep lakes averages about $2 \mathrm{~m}$ in thickness. The actual thickness depends on several factors such as autumn and winter temperatures and the timing and thickness of the snow cover. The shallow portions of the ice cover are near shore and melt first aided some by snow-melt water flowing from the surrounding tundra surface. As the lake ice melts 
it shifts with wind and causes some erosion on the downwind side of the lake. Further, lake enlargement is enhanced because wind generated waves along with increased air and water temperatures impact the shore line.

\section{The role of the river}

The major cause of lake tapping is the bank erosion that occurs during river channel migration. Unlike in lakes, where water levels vary little during the year, river levels are quite seasonal. The permafrost dominated environment is covered by snow and ice until snow-melt begins about midMay. Breakup, which soon follows, usually accompanies maximum flooding. The stage, velocity, turbidity and erosive potential are then high, a condition that lasts for two to three weeks. It is also the time when the maximum amount of suspended material is transported into delta areas subject to flooding.

In so far as riverbanks are concerned, the maximum impact occurs during that flooding period. There is first the removal of snow drifts and then erosion of the frozen banks. Erosion is both thermal in that the relatively warm water thaws the permafrost, and mechanical through the physical action of the flowing water. Along many banks a thermo-erosional niche, at times several metres deep, develops enhancing bank retreat (Walker 1969).

\section{TAPPED LAKES AND DEPOSITION}

With the combination of lake expansion and channel migration, few areas within the delta are immune from modification. Thus, lake and pond tapping and draining are frequent occurrences. Even ponds perched above flood level are not exempt. When riverbank erosion destroys the rims of ponds they drain (Fig. 3). If they are located below flood level, once breached, they become traps for ice-rafted debris as well as flood carried drift wood and sediment.

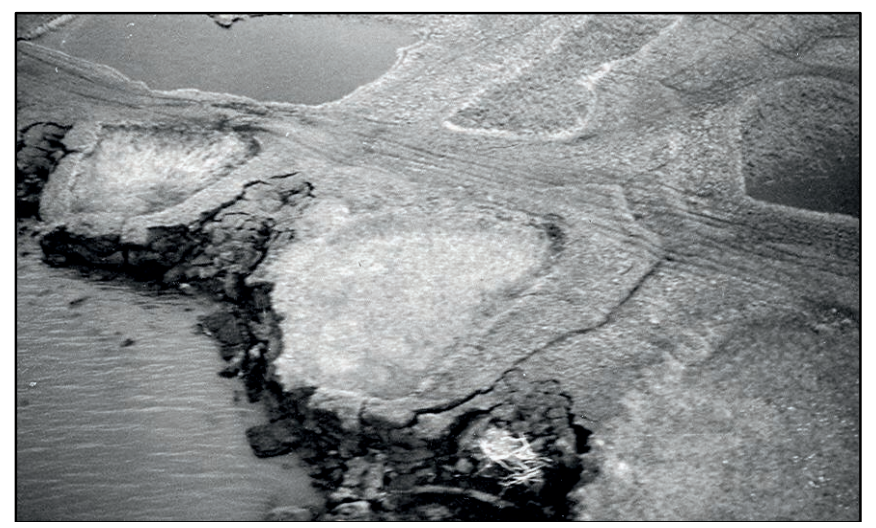

Fig. 3 High level ice wedge polygon pond drained because of riverbank erosion.

Although such pond destruction is frequent and wide spread, a much more dramatic occurrence is the tapping of the delta's larger lakes. This process has occurred so often in the Colville delta that it now contains numerous lakes that are connected to the river (Fig. 1(b); Roselle \& Walker 1996). All stages of creation and destruction are present.

Untapped lakes within the delta have levels that are higher than normal river level so that the gradient down from lake to river results in rapid flow to the river once tapping occurs. Erosion resulting from lake discharge widens the breach and also creates a scour hole at the exit location. Some scour holes have depths of as much as $10 \mathrm{~m}$ (Roselle 1988).

Once a lake is tapped, it has a level that subsequently fluctuates with river stage. Because the normal river stage is lower than the former lake level, erosional benches that surround many of the lakes become sub-aerial terraces. Thus, in most cases, water areas in lake basins are immediately reduced.

Much more significant is the opening of the former lake to the sediment-laden water of the flooding river. The water entering the lake basin spreads out, decreases in velocity and selectively 
deposits its sediment. The tapped lake thus becomes a settling basin with a gradation of decreasing texture inward from the mouth. The coarsest material is deposited first just in from the entrance. As deposition continues, most lake basins become divided resulting in the formation of two or more smaller lakes. As the basin begins to fill the new deposits are exposed to the atmosphere with its very low winter temperatures and permafrost development with ice wedges will form. In addition, once flood waters have drained from a tapped lake, the surface dries out rapidly and the freshly deposited sediment is susceptible to wind erosion.

\section{LAKES NANUK, TUTTUT AND 35}

With aerial photography dating back to 1948 and more recently Landsat, and with periodic field seasons beginning in 1961, numerous lakes in the Colville delta have been examined. Three lakes that illustrate lake tapping and conversion into settling basins are Lake Nanuk, Lake Tuttut and Lake 35 (A, B and C, respectively, Fig. 1(a)). Lake Nanuk (Polar Bear Lake), located on the Niglik channel $10 \mathrm{~km}$ north of the present town of Nuiqsut, was tapped during the early 1940s; Lake Tuttut (Caribou Lake), located on one of the smaller distributaries (Sakoonowg channel), was tapped in 1971; and Lake 35, located on one of the exit channels near the eastern front of the delta, was tapped about 1966.

Lake Nanuk, with an original area of $2.51 \mathrm{~km}^{2}$, has a highly varied shoreline that includes tundra polygons, peat banks, sand dunes, wave cut benches, and a pingo. Although we do not know the depth of the original lake, we calculate that it was 3 to $4 \mathrm{~m}$ and that it stood 2 to $3 \mathrm{~m}$ above the normal summer level of the river. Although some filling had already occurred in Lake Nanuk by 1962 when the first survey was made, it was still possible to traverse it by boat and get depth measurements (Fig. 4(a)). The latter show that the subaqueous delta was growing to the north faster than to the south. Filling was so rapid that, by 1972, boat movement in the lake was impossible and by 1983 the lake delta extended all of the way to the north shore. During the approximately 75 years since the lake was breached, the amount of standing water in its basin has decreased steadily (Table 1, Fig. 4(b)).

In 1983, by which time nearly half of the former lake had become sub aerial, a set of sediment samples were collected from five distinct lake bed environments (Fig. 4(a)). The coarsest sediments (about 60\% sand) were from the apex of the lake delta. In general, texture decreases away from the apex. An exception was found at the south end of the lake where the shore line abuts sand dunes. In addition to the inorganic sediments introduced by the river, there are other materials such as organics that include drift wood, peat shreds and even caribou hair. During breakup, river ice adds erratics, especially gravel and boulders, into the mix.

Lake Tuttut, with an area of $3.79 \mathrm{~km}^{2}$ before tapping, was one of the delta's largest lakes (Fig. 5). Representing well the development of large lakes that result from the joining of several lakes through thermokarst enlargement, it lies adjacent to a small distributary that normally carries only about two percent of the total discharge of the river. Nonetheless the channel is migratory and actively eroded the bank that separated it from Lake Tuttut. In 1971, ice-wedge melt and permafrost thaw within the bank between the lake and channel aided in the tapping process. Because the bottom of Lake Tuttut, unlike that of Lake Nanuk, was uneven, large areas became sub aerial once draining occurred (Table 1, Fig. 5). Subsequent to 1971, flood-water transported sediment into the lake basin, a lake delta began to form and some sediment was transported throughout the lake basin. However, the immediate reduction in water area in Lake Tuttut was more the result of the drainage from the shallow portions of the lake than from deposition (Roselle \& Walker 1996).

The northeastern part of the Colville delta has a number of large lakes four of which, although close together, were not connected in 1948-9 when the first aerial photographs were taken (Fig. 6). Since then, ice-wedge melting and polygon degradation have connected them. In about 1966 the river tapped the southern lake; i.e. Lake 35 in our classification. This tapping represents a more complex sequence than occurred in Lakes Nanuk and Tuttut, because it later resulted in a realignment of the distributary system that was responsible for the tapping in the first place. 


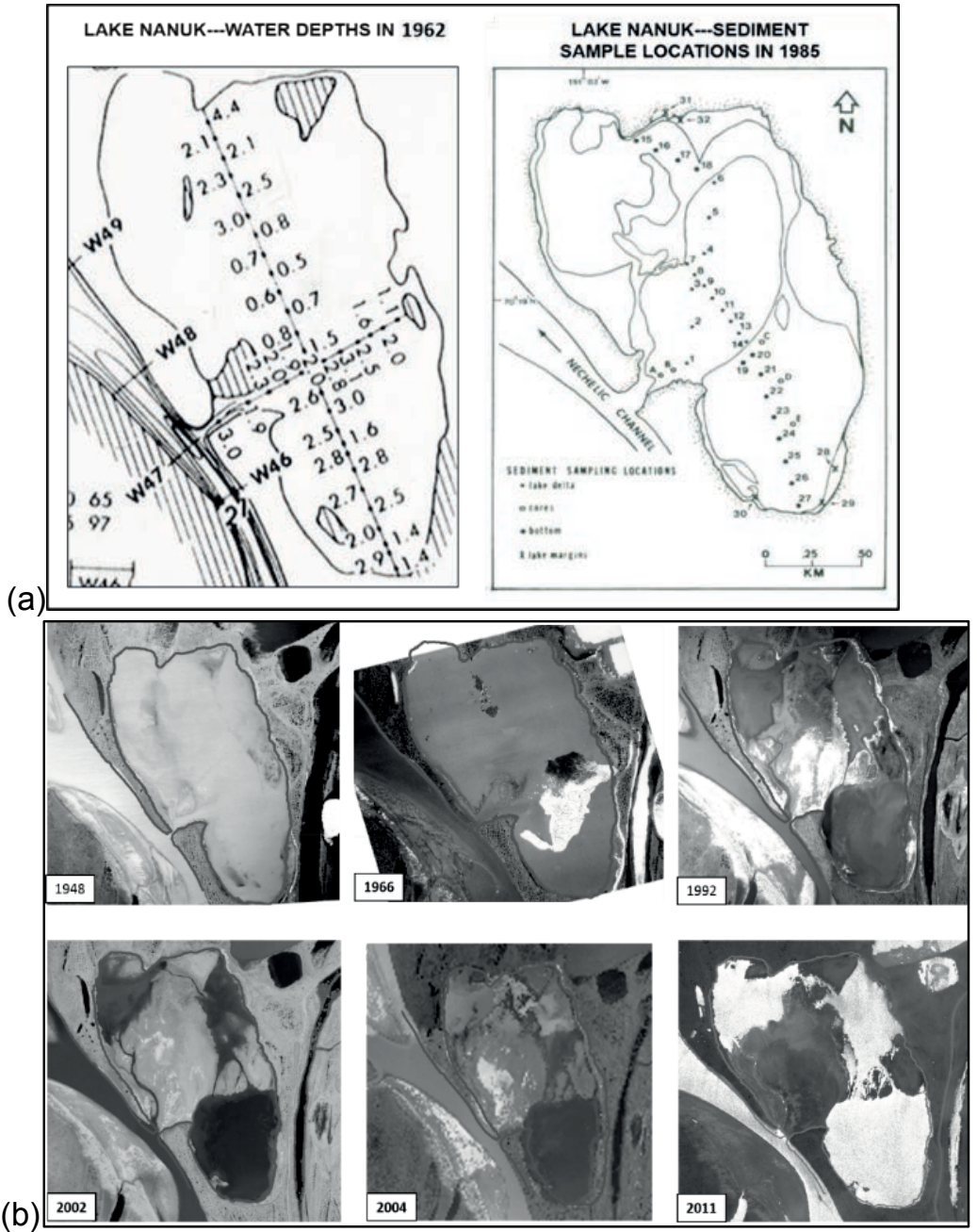

Fig. 4 Lake Nanuk: (a) surveyed, and (b) images showing the progressive tapping and filling.

Table 1 Lake size reduction after tapping, in $\mathrm{km}^{2}$.

\begin{tabular}{llllllllll}
\hline & Pre 1948 & 1948 & 1955 & 1972 & 1979 & 1981 & 1983 & 1992 & 2011 \\
\hline Lake Nanuk & 2.51 & 2.45 & 2.18 & 2.04 & 1.80 & - & 1.43 & - & 1.76 \\
Lake Tuttut & 3.79 & tapped 1972 & 3.44 & 2.29 & - & 2.21 & - & 1.63 \\
Lake 35 & 1.03 & tapped $\sim 1996$ & - & - & 0.81 & - & 0.63 & 0.51 \\
\hline
\end{tabular}

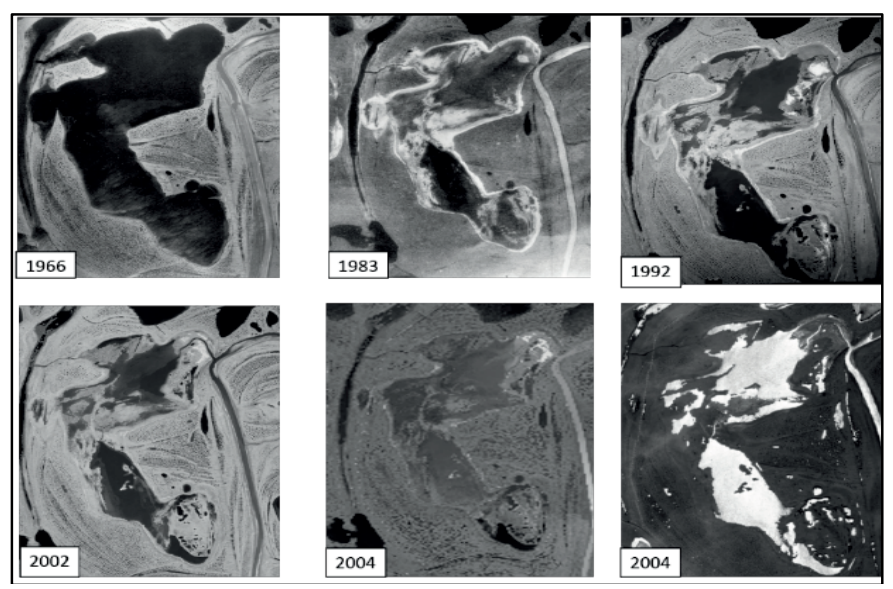

Fig. 5 Images of Lake Tuttut showing progressive filling since it was tapped in 1972. 


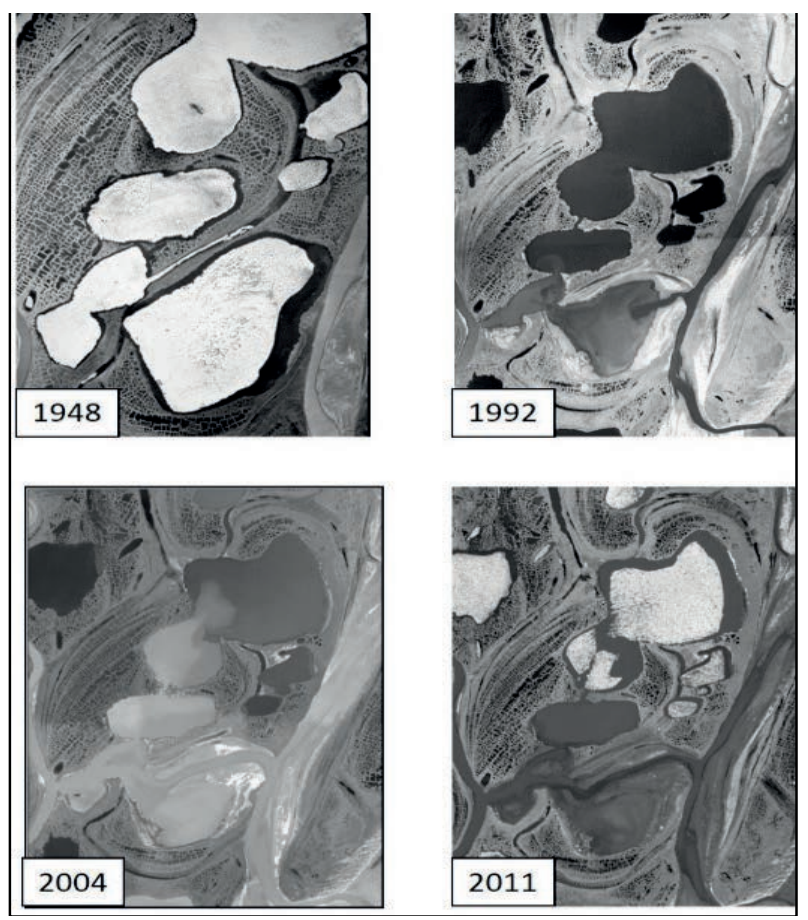

Fig. 6 Images of Lake 35 showing progressive tapping and filling.

Because, by 1970, filling had only commenced, we were able to echo-sound the lake. Filling progressed rapidly and in about 1995 the western end of the lake system was also tapped. This provided an outlet for the water from the larger eastern distributary to flow through Lake 35 and join that from a smaller western distributary, as shown in the photo sequence of Fig. 6 . Thus, the deposition sequence in Lake 35's basin has been somewhat more uniform than in most other tapped lakes. The reduction of the water surface has gone from $1.03 \mathrm{~km}^{2}$ at the time of tapping to $0.51 \mathrm{~km}^{2}$ in 2011 (Table 1).

\section{CONCLUSION}

One of the most common processes occurring in arctic deltas is the tapping of lakes which converts them into sediment traps. In the Colville River delta in northern Alaska, such tapping has been so frequent that today the delta's landscape contains examples of lakes ranging from freshly tapped to those that are largely destroyed by the river's migrating distributaries.

\section{REFERENCES}

Carter, L. D., Heginbottom, J. A. \& Woo, M. (1987) Arctic lowlands. In: Geomorphic Systems of North America (ed. by W. L. Graf), 583-628. Geological Society of America, Inc.

Dawson, A. G. (1975) Landforms of the Colville River delta, Alaska, as interpreted from aerial photographs. Unpublished MSc Thesis, Louisiana State University, Baton Rouge, LA, USA.

Jorgenson, T. M. \& Shur, Y. (2007) Evolution of lakes and basins in northern Alaska and discussion of the thaw lake cycle. Journal of Geophysical Research, 112, 1-12.

McGraw, M. \& Walker, H. (2013) Reassessment of lakes and ponds in an Arctic river delta using modern spatial technology. In: Proceedings, Tenth International Conference on Permafrost (ed. by K. Hinkle), 255-260. The Northern Publisher, Salekhard, Russia.

Ritchie, W. \& Walker, H. (1974) Riverbank forms of the Colville River Delta. In: The Coast and Shelf of the Beaufort Sea (ed. by J. Reed \& J. Sater), 545-562. The Arctic Institute of North America. Washington, DC. USA.

Roselle, D. L. (1988) Morphology and Sedimentation of Arctic Tapped Lakes. Unpublished MSc Thesis, Louisiana State University. Baton Rouge, LA. USA.

Roselle, D. L. \& Walker, H. J. (1996) Erosional and depositional history of two deltas in Arctic Alaska. Heidelberger Geograpische Arbeiten 104, 413-426.

Walker, H. (1970) Some aspects of erosion and sedimentation in an arctic delta during breakup. In: Symposium on the Hydrology of Deltas (Actes due Colloque de Bucarest—mai 1969). IAHS Publs 90/91, 209-219.

Walker, H. (1973) Spring discharge of an arctic river determined from salinity measurement beneath sea ice. Water Resources Research. 9(2), 474-480. 